\title{
STUDY OF SYNTHESIS PROCESSES OF HEAT-INSULATING SILICATE MATERIALS FOR EXTERNAL PROTECTION OF STEEL OIL PIPELINES
}

\author{
E. A. Yatsenko ${ }^{1}$, B. M. Goltsman ${ }^{1}$ \\ 1 Platov South Russian State Polytechnic University (Novocherkassk, Russia)
}

E-mail:e_yatsenko@mail.ru; boriuspost@gmail.com

\section{AUTHOR'S INFO \\ E. A. Yatsenko, \\ Dr. Eng., Prof., \\ Head of the Dept. \\ "General Chemistry \\ and Technology of \\ Silicates", \\ B. M. Goltsman, \\ Cand. Eng., Associate \\ Prof., Dept. "General \\ Chemistry and \\ Technology of Silicates"}

\section{Key words:}

steel oil pipeline, thermal insulation, silicate materials, foam glass, melting, foaming, diatomite.

\author{
A B S T RACT
}

\begin{abstract}
Thermal insulation of steel oil pipelines allows to extend their service life and provide optimal characteristics of the petroleum products transportation. Currently used heat-insulating materials do not meet the requirements of durability and fire safety. Their most promising replacement is porous silicate materials, and one of their main advantages is the possibility to use various types of local raw materials. On the basis of the diatomite of the Chernoyarskoe deposit, the initial batch compositions were developed, their synthesis was carried out by the hydrate foaming mechanism, after which the density of the synthesized samples was determined and their internal structure was studied. The effect of each of the batch components on the intensity of melting and foaming of the initial diatomite was established. It was shown that the introduction of sodium hydroxide lowers the melting point, and the removal of chemically bound water during heating allows to obtain a porous structure. Sodium fluoride, which was introduced as flux, significantly reduces the viscosity of diatomite and, accordingly, the melting point. Using the differential thermal analysis, the physicochemical processes occurring during the thermal treatment of samples were investigated. It was found that mass loss is ensured by the removal of physically and chemically bound water at temperatures of $66.8-75.2^{\circ} \mathrm{C}$ and $119.5-124.8^{\circ} \mathrm{C}$, respectively. Moreover, for compositions with the addition of sodium hydroxide, the total amount of bound water reaches $22.99-24.25 \%$ due to the dehydration of sodium hydrosilicates. When processing the batches, observed endothermic effects were corresponded to the evaporation of physically and chemically bound water, and the polymorphic $\beta$-quartz $\rightarrow \alpha$-quartz transformation at $575^{\circ} \mathrm{C}$. The revealed regularities of the mechanism of diatomaceous raw materials foaming of make it possible to optimize the developed compositions and to obtain high-quality heat-insulating material for pipeline protection.
\end{abstract}

\section{Introduction}

Transportation of oil products is a complex scientific and technological task requiring an integrated approach, the implementation of which is carried out mainly using steel pipelines. All sections of oil pipelines must be protected from negative impact. A special influence on the transported products is exerted by an external temperature effect, which can affect the speed of oil movement. Thermal insulation of oil pipelines performs several tasks: preventing the appearance of condensate on the pipe surface; decrease in corrosion rate; minimization of heat loss; protection of the pipe surface from high temperatures, etc. Thus, the main task of isolation is bilateral protection, which ensures both the preservation of the quality of the transported oil and environmental safety [1-4].

Since thermal insulation material for oil pipelines has a number of specific tasks, special requirements are imposed on it. In addition to low thermal conductivity, it must be strong, durable, non-combustible, vapor-proof and easy installation. At present, a number of modern materials can be used as a substitute for the previously most popular insulating material - asbestos. The most popular materials among them are polyurethane foam and foamed rubber.

Polyurethane foam is a gas-filled polymer with low thermal conductivity and vapor permeability. The closed porous structure of polyurethane foam makes it light- weight, wear-resistant and resistant to temperature drops. This material is applied to the pipe surface by applying a liquid composition with a brush or spray. Foamed rubber is a closed-cell foam elastomer, characterized by anticorrosion properties, resistance to aggressive chemicals, flexibility and ease of installation [5-6].

The main disadvantage of the above materials is their low fire resistance. Like other polymeric materials, both polyurethane foam and rubber are highly combustible, and a whole range of toxic substances is released during combustion. In this regard, recently, porous silicate materials synthesized using foam glass technology are increasingly being used as a thermal insulation material for protecting oil and gas engineering networks. The structure of this type of material can be described as gas-filled pores separated by thin walls of silicate mass. As a result, foam glass materials have a unique set of properties: low thermal conductivity, high strength, durability, biological and chemical resistance, complete non-combustibility, etc.

An important technological parameter in the synthesis of the material is the availability of a sufficient raw material base. As a result, the synthesis technology of porous silicate materials based on local raw materials was developed earlier [7-9] to protect the Far East oil pipeline network. Foaming was carried out using hydrate mechanism [10-13]. The obtained data confirmed the high thermal-insulating properties of the material. So, the aim of this work is to study the processes that occur 
during the heat treatment of the developed thermal-insulating silicate materials.

\section{Materials and Methods}

The main raw material for the synthesis of foam glass was diatomite of the Chernoyarsk deposit, including, wt. \%: $\mathrm{SiO}_{2}-76.19 ; \mathrm{Al}_{2} \mathrm{O}_{3}-6.76 ; \mathrm{Fe}_{2} \mathrm{O}_{3}-3.54 ;$ $\mathrm{CaO}-1.04 ; \mathrm{MgO}-0.92$; LOI -11.55 .

\begin{tabular}{|c|c|c|c|c|c|c|}
\hline \multicolumn{6}{|c|}{ Batch composition and density of the synthesized samples } \\
\hline \multirow{2}{*}{ Composition } & \multicolumn{3}{|c|}{$\begin{array}{c}\text { The content of the component, wt. } \\
\%\end{array}$} & \multicolumn{2}{|c|}{$\begin{array}{c}\text { The density of the composition, } \\
\mathrm{kg} / \mathrm{m}^{3} \text {, at a temperature, }\end{array}$} \\
\cline { 2 - 7 } & Diatomite & $\mathrm{NaOH}$ & $\mathrm{NaF}$ (over 100) & 800 & 850 & 900 \\
\hline 1 & 100 & - & - & 1290 & 1268 & 1316 \\
\hline 2 & 80 & 20 & - & 545 & 359 & 424 \\
\hline 3 & 100 & - & 5 & 1349 & 1320 & 1262 \\
\hline 4 & 80 & 20 & 5 & 473 & 756 & Full melting \\
\hline
\end{tabular}

The process of diatomite preparion included drying at $105 \pm 5^{\circ} \mathrm{C}$ for 2 hours; grinding to a particle size of less than $250 \mu \mathrm{m}$ (passing through a standard sieve No. 60), which corresponds to a specific surface of $3000 \mathrm{~cm}^{2} / \mathrm{g}$.

A powder of sodium hydroxide $(\mathrm{NaOH})$ was used as a foaming agent. It was mixed with distilled water to obtain a $50 \%$ aqueous solution. Then, the solution was added to the diatomite powder in the ratio "diatomite $: \mathrm{NaOH}$ $($ dry $) "=$ "80:20" and stirred for 30 minutes. The mixture was kept at $50{ }^{\circ} \mathrm{C}$ for 1 hour to intensify the interaction between the components. Cubic samples with a face length of $20 \mathrm{~mm}$ and a mass of $10 \mathrm{~g}$ were formed from the resulting mixture by uniaxial pressing with a load of $5 \mathrm{MPa}$. The obtained samples were placed on a grid substrate and loaded into an electric furnace for heat treatment in an air atmosphere in accordance with the regime [7].

According to the regime, the samples were loaded into a furnace at $600{ }^{\circ} \mathrm{C}$, heated to a predetermined foaming temperature $\left(800,850,900^{\circ} \mathrm{C}\right)$ at a rate of $6^{\circ} \mathrm{C} / \mathrm{min}$. and kept at this temperature for 30 minutes. After foaming, a sharp cooling (quenching) to a temperature of $600^{\circ} \mathrm{C}$ was carried out at a rate of $70-100^{\circ} \mathrm{C} / \mathrm{min}$. Then, the samples were slowly cooled (annealed) to room temperature at a rate of $1-2{ }^{\circ} \mathrm{C} / \mathrm{min}$. After cooling to $30^{\circ} \mathrm{C}$, the samples were removed from the furnace and their average density $\left(D, \mathrm{~kg} / \mathrm{m}^{3}\right)$ was determined by the formula (1):

$$
D=m /(a \cdot b \cdot c),
$$

where $m$ - sample mass, $\mathrm{kg} ; a-$ sample length, $\mathrm{m}$; $b$-sample width, $\mathrm{m} ; c$ - sample height, $\mathrm{m}$.

Each recorded test value is an average of 5 measurements.

The processes occurring during the heat treatment of the compositions were investigated by the synchronous thermal analysis method using the STA 449 Jupiter device. Temperature range $20-850^{\circ} \mathrm{C}$; heating rate $(10 \mathrm{~K} / \mathrm{min})$, air medium, crucible type: platinum with a cover.

\section{Results and Discussion}

In this study, the so-called "hydrate" mechanism was used to foam diatomaceous raw materials. This mechanism is based on the mixing of the initial diatomite with an alkaline solution [14]. Treating diatomite with sodium hydroxide in the presence of water leads to reaction (2),

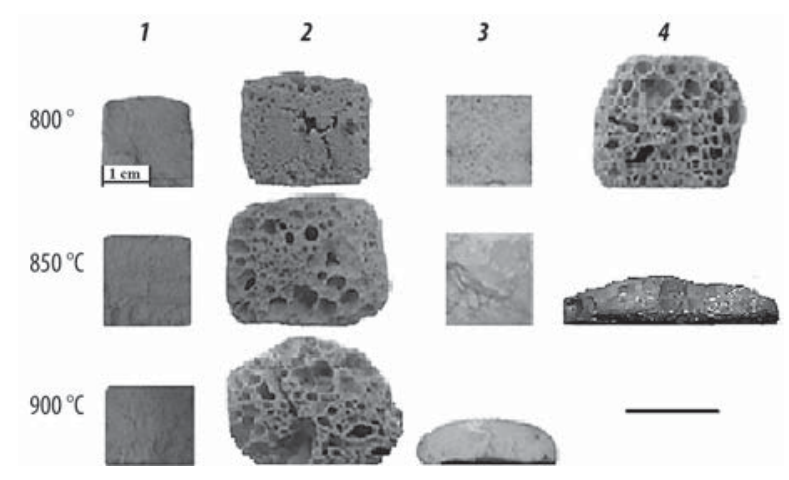

Fig. 1. Internal structure of the synthesized samples

and the formed hydrosilicates are dehydrated by the reaction (3) with further heat treatment.

$$
\begin{aligned}
& m \mathrm{SiO}_{2}+2 n \mathrm{NaOH}+ \\
& +(p-1) \mathrm{H}_{2} \mathrm{O} \rightarrow n \mathrm{Na}_{2} \mathrm{O} \cdot m \mathrm{SiO}_{2} \cdot p \mathrm{H}_{2} \mathrm{O} \\
& n \mathrm{Na}_{2} \mathrm{O} \cdot m \mathrm{SiO}_{2} \cdot p \mathrm{H}_{2} \mathrm{O} \rightarrow n \mathrm{Na}_{2} \mathrm{O} \cdot m \mathrm{SiO}_{2}+ \\
& +p \mathrm{H}_{2} \mathrm{O}\left(700-830{ }^{\circ} \mathrm{C}\right) ;
\end{aligned}
$$

Thus, the prepared mixture, in fact, is a residual (unreacted) diatomate impregnated with a colloidal solution of sodium hydrosilicate. The heating of such mixtures consisting of waterglass, organic impurities and poorly soluble crystalline components (quartz, clay minerals, feldspars, etc.) leads to foaming with the formation of cellular glass using a one-stage technology. At the same time, the evaporation of bound water during thermal decomposition of waterglass provides intensive foaming of the mass.

To study foaming processes by the hydrate mechanism, a number of compositions containing diatomite, sodium hydroxide, and flux $(\mathrm{NaF})$ in various proportions, were developed (Table). Heat treatment of the developed compositions was carried out at foaming temperatures of $800,850,900{ }^{\circ} \mathrm{C}$. The density of the obtained samples is presented in the Table, and their internal structure is shown in Fig. 1.

From the results obtained, it is possible to describe the effect of each component on the sintering and foaming of the compositions. For pure diatomite (Composition 1), temperatures below $900{ }^{\circ} \mathrm{C}$ are not enough for sintering and, especially, melting. This is confirmed by both the 


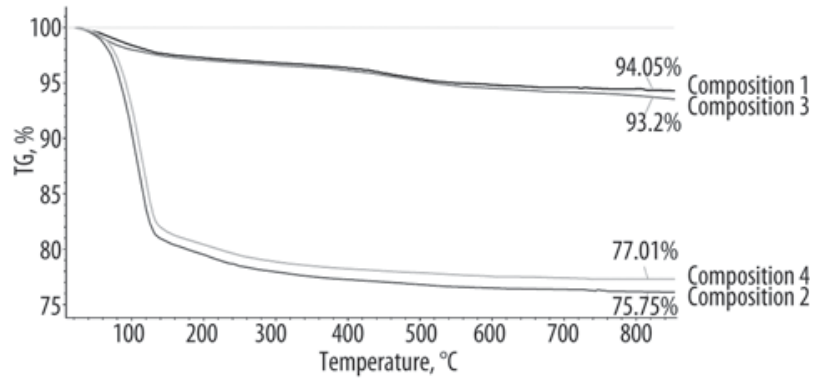

Fig. 2. Comparison of Compositions 1-4 TG-curves

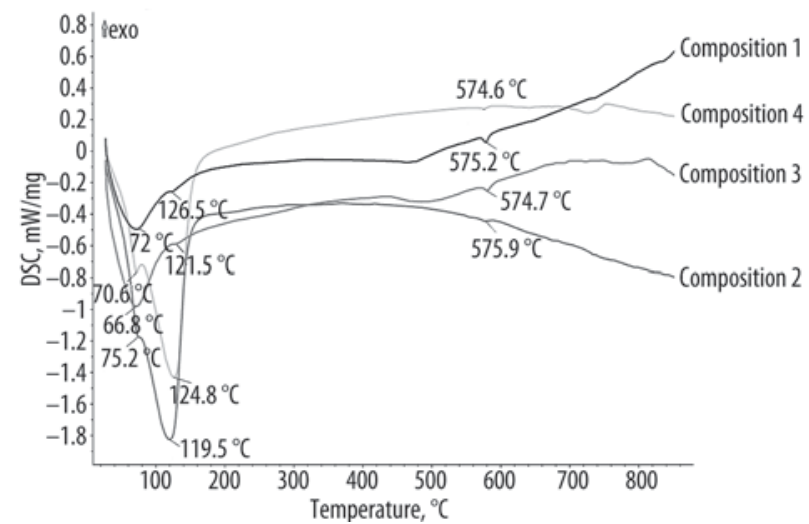

Fig. 3. Comparison of Compositions 1-4 DSC curves

color of the sample and the loose structure. The density of Composition 1 at temperatures of $800,850{ }^{\circ} \mathrm{C}$ corresponds to the density of the unsintered sample, and only at a temperature of $900{ }^{\circ} \mathrm{C}$ density begins to increase, that indicates the beginning of the sintering process.

The introduction of sodium hydroxide (Composition 2) leads to a significant decrease in the viscosity of the sample, and the release of chemically bound water according to reaction (3), that leads to the foaming of the mass. Due to an increase in gas pressure and a decrease in viscosity, the density decreases from $545 \mathrm{~kg} / \mathrm{m}^{3}\left(\right.$ at $800{ }^{\circ} \mathrm{C}$ ) to $359 \mathrm{~kg} / \mathrm{m}^{3}$ (at $850^{\circ} \mathrm{C}$ ), and a further decrease in viscosity at $900{ }^{\circ} \mathrm{C}$ leads to an increase in density to $424 \mathrm{~kg} / \mathrm{m}^{3}$ due to the subsidence of the foam under its own weight.

Addition of $5 \mathrm{wt}$. \% sodium fluoride (Composition 3) has an intense effect on reducing viscosity, resulting in a strong melting of the sample at temperatures below $900{ }^{\circ} \mathrm{C}$. The combined introduction of both $\mathrm{NaOH}$ and $\mathrm{NaF}$ allows foaming to start at substantially lower temperatures $\left(800^{\circ} \mathrm{C}\right.$ and less). However, it narrows the technological range of molding and leads to almost complete sample melting even at $850^{\circ} \mathrm{C}$.

Considering the data obtained, the method of differential thermal analysis was used to study the physicochemical processes that occur during the heat treatment of the studied compositions up to $850{ }^{\circ} \mathrm{C}$ (Fig. 2 and Fig. 3).

An analysis of the obtained TG (thermogravimetric) curves indicates the following main stages of sample mass loss:
- For Compositions 1 and 3: the mass loss is associated with the removal of physically bound water $\left(50-150^{\circ} \mathrm{C}\right)$ and further smooth removal of crystalline and chemically bound water, as well as the decomposition of carbonate and organic impurities. It is very difficult to separate these processes on the obtained curves, since they occur in the same temperature range. Mass loss ceases at a temperature of $550-580{ }^{\circ} \mathrm{C}$. The total loss in the range of $20-850{ }^{\circ} \mathrm{C}$ is $5.95-6.80 \%$. In addition, since sodium fluoride is almost completely bound to the aluminosilicate framework, the mass loss curves of compositions 1 and 3 are superimposed.

- For Compositions 2 and 4: the change in mass differs from Compositions 1 and 3 by a significant loss in the temperature range of $100-180^{\circ} \mathrm{C}(\approx 18 \%)$. This is due to the intense water release after the dehydration of hydrosilicates according to the reaction (3). The total mass loss in the range of $20-850{ }^{\circ} \mathrm{C}$ is $22.99-24.25 \%$. Otherwise, the processes of mass loss are similar for all four compositions. The absence of the $\mathrm{NaF}$ influence on the processes of mass change leads to the imposition of Compositions 2 and 4 curves.

DSC (differential scanning calorimetry) curves of the studied compositions have a number of qualitative similarities. Three endothermic peaks stand out on all the curves:

- peak at $66.8-75.2^{\circ} \mathrm{C}$, corresponding to the evaporation of physically bound water;

- peak at $119.5-124.8^{\circ} \mathrm{C}$, corresponding to the evaporation of crystalline water, including water from hydrosilicates;

- peak at $574.6-575.9^{\circ} \mathrm{C}$, corresponding to the polymorphic transformation " $\alpha$-quartz $\rightarrow \beta$-quartz».

At the same time, despite the qualitative similarity, these curves can be grouped similarly to TG-curves: Compositions 1 and 3, Compositions 2 and 4. A key difference here is also a different activity of processes in the temperature range of $100-180^{\circ} \mathrm{C}$, i.e. removal of crystalline water. For Compositions 2 and 4, it is significantly more intense than the removal of physical water, in contrast to Compositions 1 and 3, where physical water predominates. In addition, temperature increasing above $500{ }^{\circ} \mathrm{C}$ leads to a different behavior of the compositions. The curve of Composition 1, upon reaching $500{ }^{\circ} \mathrm{C}$, begins to rise, which indicates a beginning of solid-phase sintering and continues to increase up to $850^{\circ} \mathrm{C}$. At the same time, the curve of Composition 2 begins to decrease, which is connected with the melting process of sodium hydrosilicates, formed according to reactions $(2)-(3)$. The curve of Composition 3 is similar to Composition 1 up to a temperature of $700{ }^{\circ} \mathrm{C}$, but with further heating it first assumes a horizontal position, and then sharply decreases at $800{ }^{\circ} \mathrm{C}$, that could be explained by the intense melting due to $\mathrm{NaF}$ action. The shape of the curve of Composition 4 in comparison with Composition 2 changes in a similar way and is explained by the same reasons. 


\section{Summary}

Thermal insulation of steel oil pipelines allows to extend their service life and ensure optimal characteristics of the movement of oil products. The most promising substitute for combustible polymer insulation is porous silicate materials based local raw materials. The compositions of the batches based on the diatomite of the Chernoyarskoe deposit were developed, their synthesis was carried out by the hydrate foaming mechanism, the density of the synthesized samples was determined, and their internal structure was studied. It was shown that the introduction of sodium hydroxide lowers the melting point, and the release of chemically bound water during heating allows to obtain a porous structure. Sodium fluoride, introduced as flux, significantly reduces the viscosity of diatomite and, accordingly, the melting point. Using the differential thermal analysis method, it was found that mass loss is provided by the removal of physically and chemically bound water at temperatures of $66.8-75.2{ }^{\circ} \mathrm{C}$ and $119.5-124.8{ }^{\circ} \mathrm{C}$, respectively. Moreover, the total amount of bound water for Compositions 2 and 4 reaches 22.99-24.25\% due to the dehydration of sodium hydrosilicates. When processing the batches, the following endothermic effects are observed, corresponding to the described evaporation of physically and chemically bound water, and the polymorphic transformation " $\alpha$-quartz $\rightarrow \beta$-quartz" at $575^{\circ} \mathrm{C}$. The revealed regularities of diatomite foaming allow optimizing the technology and obtaining high-quality heat-insulating material for steel pipeline protection.

\section{Acknowledgements}

The work was supported by the Russian Science Foundation, Project \# 18-19-00455 "Development of integrated protection technology for oil and gas pipelines, operated in the Far East of Russia" within the framework of the 2018 competition "Conducting fundamental scientific research and exploratory scientific research by individual scientific groups".

\section{REFERENCES}

1. Baikov I. R., Kitaev S. V., Smorodova O. V., Kolotilov Yu. V. Analysis of the heat-insulating materials properties for pipeline fittings. Polymer Science. Series D. 2018. Vol. 11. No. 1. pp. 96-98.

2. Kovalevsky V. B. Thermal insulation for objects of pipeline oil transportation. Tekhnologii toplivno-energeticheskogo kompleksa. 2006. No. 1. pp. 58-63.

3. Bagautdinov A. E., Yarullin B. L. Thermal insulation of main oil pipelines. Alleya nauki. 2018. Vol. 8. No. 5 (21). pp. 22-28.

4. Kovalevsky V. B. Energy Efficiency of Thermally Insulated Underground Oil Pipelines. Truboprovodnyy transport: teoriya i praktika. 2010. No. 3 (19). pp. 25-27.

5. Mkhitaryan V. A. Consumption of polyurethane foam and equipment for its production. Stroitelnyye materialy. 2005. No. 6. pp. 23-24.

6. Loginova N. A., Lapin E. E., Batrakov A. A., Grigoryev S. V., Ryzhenkov A. V., Volkov A. V. Overview of thermal insulation materials used in the construction and operation of oil pipelines and station equipment oil heating. Neftyanoye khozyaystvo. 2015. No. 9. pp. 126-129.

7. Yatsenko E. A., Ryabova A. V., Goltsman B. M. Development of fiber-glass composite coatings for protection of steel oil pipelines from internal and external corrosion. Chernye Metally. 2019. No. 12. pp. 46-51.

8. Yatsenko E. A., Goltsman B. M., Smolii V. A., Goltsman N. S., Yatsenko L. A. Study on the possibility of applying organic compounds as pore-forming agents for the synthesis of foam glass. Glass Physics and Chemistry. 2019. Vol. 45(2). pp. 138-142.

9. Yatsenko E. A., Goltsman B. M., Ryabova A. V. The study of the microstructure of glass composite coatings to protect steel pipelines against internal and external corrosion. Chernye Metally. 2020. No. 4. pp. 46-51.

10. Vaisman Ya. I., Ketov A. A., Ketov Yu. A., Slesarev M. Yu. The expansion kinetics of cellular glass in the thermoplastic state under the hydrated mechanism of gas formation. Glass Physics and Chemistry. 2017. Vol. 43. pp. 330-334.

11. Ivanov K. S., Radaev S. S., Selezneva O. I. Diatomites in Granular Foam-Glass Technology. Glass and Ceramics. 2014. Vol. 71.pp. 157-161.

12. Silva R., Kubaski E., Tenório-Neto E. et al. Foam glass using sodium hydroxide as foaming agent: Study on the reaction mechanism in soda-lime glass matrix. Journal of Non-Crystalline Solids. 2019. Vol. 511. pp. 177-182.

13. Vereshagin V. I, Sokolova S. N. Granulated foam glass-ceramic material from zeolitic rocks. Construction and Building Materials. 2008. Vol. 22. pp. 999-1003.

14. Melkonyan R. G. Amorphous rocks and glass making. M.: NIA-Priroda. 2002. 264 p.

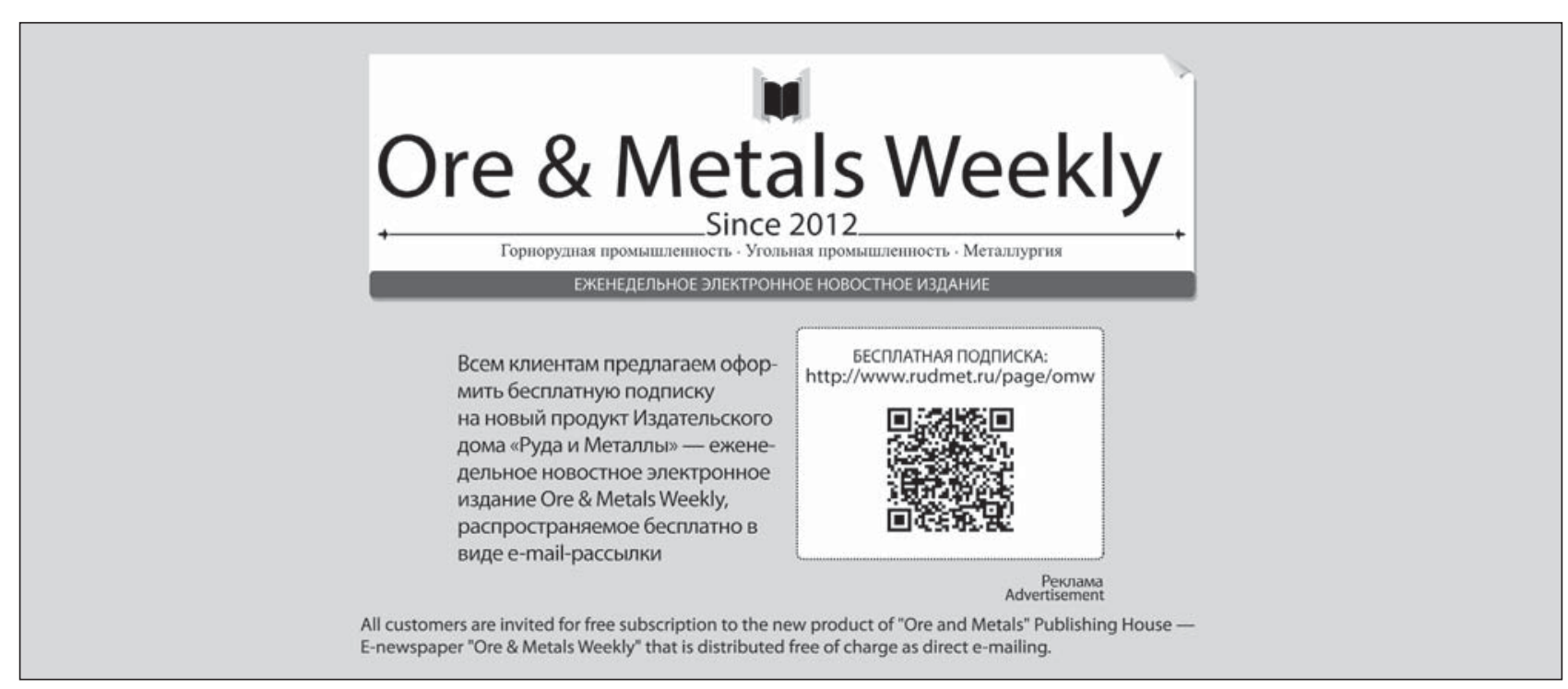

